\title{
Traditional CSR Vs Creating Shared Value: A Process of Stakeholder Engagement.
}

\author{
Alpana \\ (Assistant Professor, SRCC, University of Delhi)
}

\begin{abstract}
The household CSR seldom focuses on large-scale effects and has not created systemic solutions to India's most pressing social issues. CSV force firms to view social progress as a key factor in the development of their business strategy. CSV starts from a different point of view than traditional CSR. Responding to social concerns does not require a trade-off against corporate profitability rather companies can advance their economic interests precisely by creating new value through thoughtful, strategic initiatives that simultaneously contribute to society as a whole. In India, corporations that follow the CSV vision often intend to reconceived products and markets to meet the needs of low-income and rural populations this is possibly not unexpected, as the nation is home to millions of people who lack access to basic products and services through conventional channels consider a company that makes hygiene products. At present inclusive growth and creating shared value is a more powerful approach than traditional CSR, and India has an opportunity to lead the global dialogue about a more balanced form of capitalism. This a apt time for a new approach which focuses on business resources directly on balancing economic and social interests to create meaningful impact, strengthening the country's long-term economic attitude.
\end{abstract}

Keywords: CSR, CSV, Performance Gap, Shareholder Value, Stakeholder Engagement.

\section{Introduction}

Corporate social responsibility means are responsibility of a corporation towards the society in a manner which serve the best interest with the organizations own interest. Earlier CSR is considered as corporate philanthropy which means donations given by the organization to the public for their betterment but now the scenario has changed CSR becomes the hottest and most talked about issue all over the world. It first emerged in USA in the arena of 1950 as philanthropy donation but now the whole concept of CSR has changed; its focus has shifted from obligation to CSR as a strategy.

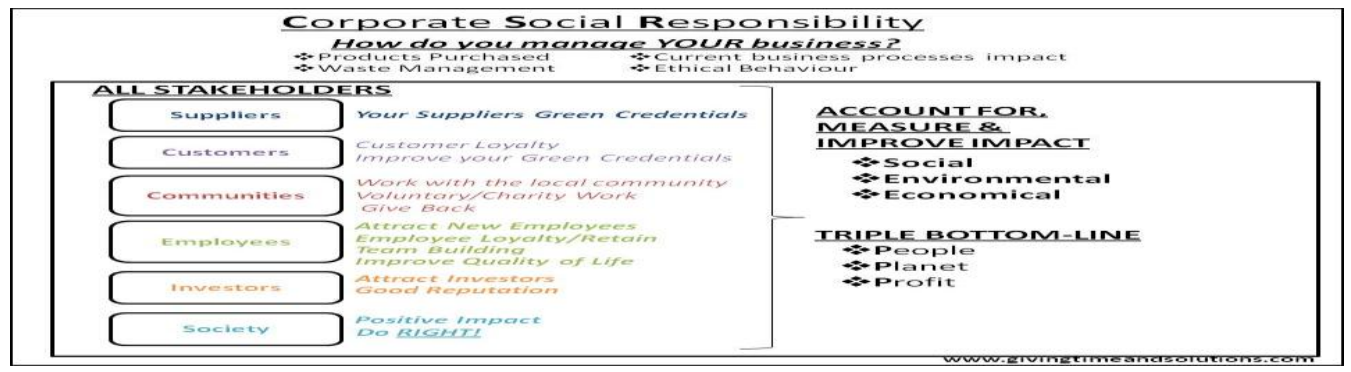

\section{Review of Literature}

Carroll (1991); The Carroll's model explains that as a CSR, society basically expects four types of expectation by the organization to fulfill. (1) Economic Responsibity. (2) Legal Responsibity (3) Ethical Responsibility. (4) Discretionary Responsibility. There are three main perspective of CSR based on the point ethical business based on social values and the stake holders long time interest. The triple bottom line approach of CSR state that organization should respect its three important parts namely people, planet and profit. The corporation should care about the sake of all this three part at the time of making decision and performing activities. The people include all the human beings related to the organizations that can be employee's suppliers, owners or community. The triple bottom line reporting approach suggests that the organization has to report on all the three financial, social and environment impact of business activities. CSR is basically shows the expectation of society in different way for example; fair and clear operating practices ,consumer protection, anti-corruption and fraudulent behavior etc.

$\mathrm{CSR}=\mathrm{Pm}+\mathrm{Cs}+\mathrm{SEC}$

The equation states that profit maximization through customer's satisfaction but without affecting society an environment. 
Freeman (1984); The term stakeholder is first used by the freeman and he defined the term stakeholder as 'those groups without whose support the organization would cease to exist.

Miles, Morgan P., and et al (2006); The explicitly engaging stakeholders in the CSR strategy-making process, through the mechanism of strategic conversations, will minimize future stakeholder concerns and enhance CSR strategy making. The stakeholders in a firm are individuals and community that contribute, either voluntarily or involuntarily, to its wealth-creating capacity and activities, and who are therefore its potential beneficiaries and/or risk bearer. Now in order to improve competitive positioning, many corporations worldwide redesigned corporate polices to include guidelines for appropriate responses to corporate social responsibility (CSR) issues and as part of this change, some attention has been focused on the inclusion of corporate stakeholders in the development of strategies related to social concerns. This philosophy is partly based on the premise that companies that create and implement sustain ability plans not only benefit their bottom line but they also benefit the air we breathe, the water we drink, and our standard of living. Strategic conversations are multi-directional multi dimensional communication mechanisms for better shaping and integrating the strategic intent of top management with both the firm's capabilities' and the competitive realities. For strategic conversations to be effective in strategy making, communications must explicitly involve both talking and reflective listening by all participants. Typically, strategic conversations have been used to create open channels of unfiltered information between top managers and ground level marketing, technology, and sales force employees. These conversations help the lower level employees to understand the strategic intent of top management while simultaneously enabling executive-level managers to gain a richer and more honest understanding of both the possible future the firm faces and the ability of the firm to align itself with its desired future. In the past few years, one facet of organizational planning has evolved that includes the capability of organizations to perceive what is going on in their business environments, to think through what this means for them, and then to act upon this new knowledge refer to this strategy as adaptive organizational learning, by all participants. usually, strategic conversations have been used to create open channels of unfiltered information between top managers and ground level marketing, technology, and sales force lower level employees and these conversations help the lower level employees to understand the strategic intent of top management while at the same time enabling executive-level managers to gain a richer and more honest understanding of both the possible future the firm faces and the ability of the firm to support itself with its desired future. There are two primary gaps between the perceptions of an organization's top management, lower level employees and stakeholders further he argue that strategic conversations can be used effectively to close or at least minimize these gaps.

These two gaps are

\begin{tabular}{|l|l|l|}
\hline 1. & $\begin{array}{l}\text { The } \\
\text { Performance/Capability } \\
\text { Gap }\end{array}$ & $\begin{array}{l}\text { The gap between Top Management's perception of the firm's CSR current performance and } \\
\text { its capabilities, lower level employees perception of the firm's CSR current performance and } \\
\text { its capabilities, and stakeholders' perception of the firm's current CSR performance and its } \\
\text { capabilities }\end{array}$ \\
\hline 2. & The Futures Gap & $\begin{array}{l}\text { The gap between Top Management's perception of Future and the firm's role in that future, } \\
\text { lower level employees perception of Future and the firm's role in that future, and } \\
\text { stakeholders' perception of the Future and the firm's role in that future. Those traditional } \\
\text { models of strategic decision making are not likely to support the effective adoption of CSR } \\
\text { principles that support the interests of stakeholders, top managers, and lower level } \\
\text { employees. }\end{array}$ \\
\hline
\end{tabular}

By adopting an inside-out perspective to strategic decision making in which managers believe that what is good for managers must be good for the firm and what is good for the firm is also good for stakeholders is unlikely to advance a CSR position. The relationships between companies and stakeholders can be explained in terms of two items: (i) restrictions and (ii) exchange.

According to the company's point of view stakeholders function as restrictive factors in some respects and as resource-exchange partners in others. Therefore, when companies pay attention to their relationships with stakeholders, the specific characteristics of these relationships have come to be the basic basis of the appraisal however there has been a change in relationships between companies and stakeholders, which has added a new term value creation and this is mainly noticeable in the case of relationships between CSR and stakeholders, and this gradually become more extensive trend, so result of it energetic dialogue are taking place between companies and stakeholders.

Tokoro, Nobuyuki (2007); The four step model to design the stakeholder dialogue is as follow

\begin{tabular}{|l|l|}
\hline Step 1 & $\begin{array}{l}\text { Designing a dialogue system must be for the company in question to achieve a full understanding of its internal } \\
\text { and external environments. This should involve as accurate an understanding as possible of the problems with } \\
\text { which the company is face externally and internally, and the issues that will have to be overcome in order to } \\
\text { continue to grow. In achieving this understanding, the important issue that will arise is what is hoped to be } \\
\text { achieved from the stakeholder dialogue. }\end{array}$
\end{tabular}


Traditional CSR Vs Creating Shared Value: A Process of Stakeholder Engagement.

\begin{tabular}{|l|l|}
\hline & \\
\hline Step 2 & $\begin{array}{l}\text { The existence of stakeholders connected with the corporate process must be acknowledged, and an } \\
\text { understanding should be achieved as to their current and hoped-for links with the company. The diversity of } \\
\text { stakeholders is affected by the nature of the company, such as its field of business, its size, and whether it is } \\
\text { global or national. The company must acknowledge the existence of important stakeholders, and then analyze its } \\
\text { connections with them, involving an understanding of the details of their and its activities. }\end{array}$ \\
\hline Step 3 & Define the aims and targets of the dialogue \\
\hline Step 4 & $\begin{array}{l}\text { Consists of verifying the results of the dialogue. However, one point to which attention must be given in this } \\
\text { respect is that the results of dialogue do not necessarily all have short-term or immediate effect }\end{array}$ \\
\hline
\end{tabular}

The actual value created by stakeholder dialogue, and a number of differences in the approach to this assessment can be seen between Japan and the West. There is a strong feeling among US and European companies that it is necessary to assess as objectively as possible the value creation branching from stakeholder dialogue. Japanese companies, on the other hand, have only recently started experimenting with stakeholder dialogue, for the view that the formal objective approach is highly unsuitable, and that it is difficult to predict the creation of value occurring unexpectedly. When dialogue is carried out in such a formal manner, innovation does not arise through the process of objective theoretical analysis, but on the contrary, often occurs in the midst of various types of ambiguous, contradictory, and confrontational situations. It means that organizations always contain various contradictions and confrontational elements, and all it needs is a chance event to bring these into the open. When stakeholder dialogue is taking place, the company is in a condition of challenge and argument in which various ideas and types of agreement and criticism are being exchanged, and it has to be expected that on occasion offensive opinions will be expressed aggressively. The ideas and interests of companies, shareholders and NPOs are different, and it should therefore be recognized that in some cases these parties will have a collision aggressively. As it is the awful process of finding the points of compromise when opinions clash violently that has the potential to stimulate new perspectives and insights, and to create value. If contradiction and confrontations have not happened between the stakeholder and company there may be no value creation for the company. The formation of close relationships with various kinds of stakeholders is becoming an obligatory part of business management, and the framework for analysis of business management is as a result no longer only a matter of internal organization, nor on a small number of specific stakeholders so it is necessary to change and widen the framework to take into account relationships with a wide range of stakeholders. In other words, there is a need for perspectives that enable companies to be viewed as parts of society. There is a need for qualitative improvements in stakeholders. In other words, in order to move towards a situation in which there is not just dialogue, but value-creating dialogue, higher stakeholder quality is essential.

Freeman, Edward R. and Velamuri, Ramakrishana S. and et al (2006); The study suggest the four Levels of Commitment to the Stakeholder Approach is as follow

\begin{tabular}{|l|l|l|}
\hline Level 1 & $\begin{array}{l}\text { Basic Value } \\
\text { Proposition }\end{array}$ & $\begin{array}{l}\text { At this basic level, the entrepreneur or manager needs to know how the firm can make the } \\
\text { customer happier, and all together offer a striking value proposal to employees, suppliers, } \\
\text { communities, and financiers. }\end{array}$ \\
\hline Level 2 & $\begin{array}{l}\text { Sustained } \\
\text { stakeholder } \\
\text { cooperation }\end{array}$ & $\begin{array}{l}\text { The competitive, macro-economic, regulatory, and political environments are so dynamic } \\
\text { they necessitate constant revision of the initial stakeholder arrangements. Each revision } \\
\text { upsets the delicate balance struck in the basic value propositions to various stakeholders. } \\
\text { Managers must have a deep understanding of how these trade-offs affect each stakeholder, } \\
\text { the amount of sacrifice a given stakeholder will accept, and how these current sacrifices can } \\
\text { be compensated }\end{array}$ \\
\hline Level 3 & $\begin{array}{l}\text { An understanding } \\
\text { of broader } \\
\text { societal issues }\end{array}$ & $\begin{array}{l}\text { Managers must be aware of and react to a rising number of international issues, without the } \\
\text { moral scope of the nation, state or religion as a guide. Managers may need to take positions } \\
\text { on issues that apparently are not purely business related. A pro-active attitude is necessary } \\
\text { towards all stakeholder groups, both primary, i.e., those that have direct business dealings } \\
\text { with the company, and secondary, such as NGOs and political activists, who can affect the } \\
\text { operations of the company. }\end{array}$ \\
\hline Level 4 & Ethical leadership & $\begin{array}{l}\text { The researches which are conducted earlier pointed out to a strong connection between } \\
\text { ethical values and positive firm outcomes such as sustained profitability and high } \\
\text { innovation. The proactive ethical leadership is possible only if there exists a deep } \\
\text { understanding of the interests, priorities, and concerns of the stakeholders. }\end{array}$ \\
\hline
\end{tabular}

There are 10 general principles that jointly develop a "mindset" required for entrepreneurs and mangers to understand and practice all above explained four levels of Company Stakeholder Responsibility. There explanation is as follow 
Traditional CSR Vs Creating Shared Value: A Process of Stakeholder Engagement.

\begin{tabular}{|c|c|c|}
\hline 1. Principle & $\begin{array}{l}\text { Bring stakeholder interests } \\
\text { together over time }\end{array}$ & $\begin{array}{l}\text { It means that the very idea of supervision for stake-holders is that the } \\
\text { practice of value creation is a joint process. Companies need to show } \\
\text { returns to its shareholders, meet obligations to debt holders, banks, and } \\
\text { others. Profits don't divergence with other stakeholders they are a } \\
\text { scorecard representing how well the company is managing the whole set } \\
\text { of stakeholder relationships. So managers must keep these stakeholder } \\
\text { interests in balance, hopefully jointly reinforcing each other. }\end{array}$ \\
\hline 2. Principle & $\begin{array}{l}\text { Recognize that stakeholders } \\
\text { are real and complex people } \\
\text { with names, faces and values. }\end{array}$ & $\begin{array}{l}\text { Generally it's considered that business people are only in it for their own } \\
\text { only just for their self-interest. Business works in division because of the } \\
\text { need to create things with others and for others. Employees are extreme } \\
\text { more motivated to give their time, energy and creativity when they } \\
\text { believe in their firm's overall mission and goals. So the firm in turn needs } \\
\text { to survive its ethics. }\end{array}$ \\
\hline 3. Principle & $\begin{array}{l}\text { Seek solutions to issues that } \\
\text { satisfy multiple stakeholders } \\
\text { simultaneously }\end{array}$ & $\begin{array}{l}\text { The Issues and problems come at managers from many sources, in many } \\
\text { forms. Managers need to find ways to develop programs, policies, } \\
\text { strategies, even products and services that satisfy multiple stakeholders } \\
\text { all together the first step in that process is to actually recognize the need } \\
\text { to look for simultaneous solutions. }\end{array}$ \\
\hline 4. Principle & $\begin{array}{l}\text { Engage in intensive } \\
\text { communication and dialogue } \\
\text { with stakeholders mean that } \\
\text { not just those who are } \\
\text { friendly. }\end{array}$ & $\begin{array}{l}\text { Clearly we need intensive dialogue through multiple methods with } \\
\text { customers, suppliers, employees, and shareholders, but communities, the } \\
\text { media, critics, and other secondary stakeholders count as well }\end{array}$ \\
\hline 5. Principle & $\begin{array}{l}\text { Commit to a philosophy of } \\
\text { voluntarism }\end{array}$ & $\begin{array}{l}\text { Business should manage stakeholder relationships, rather than leaving it } \\
\text { to government. Here in the challenge for managers is to reorient their } \\
\text { thinking and managerial processes willingly to be more responsive to } \\
\text { stakeholders. If the situation accurse where a solution to a stakeholder } \\
\text { problem is imposed by a government agency or the courts must almost } \\
\text { invariably be seen as a managerial failure. }\end{array}$ \\
\hline 6. Principle & $\begin{array}{l}\text { Generalize the marketing } \\
\text { approach }\end{array}$ & $\begin{array}{l}\text { we need to understand the stakeholder needs, using marketing techniques } \\
\text { to segment stakeholders to develop a better understanding of their } \\
\text { individual needs and using marketing research tools to understand the } \\
\text { multi-characteristic nature of most stakeholder groups }\end{array}$ \\
\hline 7. Principle & $\begin{array}{l}\text { Never trade off the interests of } \\
\text { one stakeholder } \quad \text { versus } \\
\text { another continuously over } \\
\text { time }\end{array}$ & $\begin{array}{l}\text { The principle state that it is possible to generalize this philosophy to "how } \\
\text { to serve our stakeholders." more time, more energy, or whatever the } \\
\text { relevant resource that is required by a given stakeholder group. }\end{array}$ \\
\hline 8. Principle & $\begin{array}{l}\text { Negotiate with primary and } \\
\text { secondary stakeholders }\end{array}$ & $\begin{array}{l}\text { If a group or individual can affect a company or be affected by a } \\
\text { company. Then there needs to be some interaction and some strategic } \\
\text { thinking's. }\end{array}$ \\
\hline 9. Principle & $\begin{array}{l}\text { constantly monitor and } \\
\text { redesign processes to make } \\
\text { them better serve stakeholders }\end{array}$ & $\begin{array}{l}\text { As in today's changing world no one "gets it right" all the time. Whatever } \\
\text { your relations and strategies are with stakeholders, they can always be } \\
\text { improved. }\end{array}$ \\
\hline 10. Principle & $\begin{array}{l}\text { Act with purpose that fulfills } \\
\text { commitments to stakeholders }\end{array}$ & $\begin{array}{l}\text { Act with goal of towards fulfilling your dreams and stakeholder too. } \\
\text { Businesses can have a purpose and Purpose are inspirational }\end{array}$ \\
\hline
\end{tabular}

Corporate Social Responsibility has survived its usefulness, because it is faulty in two respects as firstly it promotes the "separation thesis," the idea that business issues and social issues can be dealt with separately. This supports the destructive idea that the fundamental structure of business is either not good or is ethically neutral. A stakeholder approach recognizes the intertwined nature of economic, political, social, and ethical issues. The second drawback is CSR its focuses on corporations. Social responsibility does not only apply to corporation, it applies to all organizational forms and stakeholder approach applies as much to an entrepreneurial start-up and to a mid-sized closely-held firm as it does to a corporation with diffuse ownership. So stakeholder approach is much better than the traditional CSR approach in all contexts.

Rappaport, A. (1998); He propounded a new measure of success, which is defined as the difference between corporate value and debt.

Shareholder Value $=$ Corporate Value - Debt

Here in corporate value as the present value of cash flow from operations during the forecast period +residual value +marketable securities (and other investments that can be converted to cash and are not essential for operating the business), cash flow in this sense is the difference between operating cash inflows and outflows. The residual value is the present value of an organization for the period after the forecast period. The discounted cash flow method is better than traditional figures like 'Return on Investment' or 'Return on Equities'. So the shareholder value concept as such that is not the problem, but the misunderstanding of the people using it. 
Borgonovi, Veronica, and et al, (2011); Creating shared value is more effective than traditional approaches and corporate social responsibility (CSR) has been the primary mechanism by which Indian companies have contributed to societal development. Domestic corporations have long believed that the purpose of business extends beyond simply generating shareholder value; business should also address social problems. However, a lot of Indian companies CSR activities are comprehensible as philanthropic efforts that target the well-being of employees and local communities. While these efforts have had important results, they are rarely able to achieve a national effect that is sustainable in the long run They touch only a fraction of a company's financial resources and rely on limited opportunities for employee volunteerism, rather than capitalizing on the most valuable assets that businesses bring to bear - the full use of their core competencies while in pursuit of profit. As a result, our largest CSR efforts reach hundreds of thousands of recipients, while the need is in the millions. CSV offers an alternative path. Rather than viewing social needs as the prerogative of solely CSR and philanthropy, CSV focuses on finding the business opportunities hidden in social problems. Issues like poverty, pollution, and poor health are not externalities to be dismissed, but rather core business concerns that have a substantial impact on growth and operational efficiency. When businesses tackle social problems as a central part of their competitive strategy, they achieve large-scale and fundamentally sustainable changes in society.

Porter and Kramer (2011); The study suggests that companies create shared value in three ways. FirstlyPreconceiving products and markets: Better serving existing markets, accessing new ones, or developing innovative products that meet social needs. Secondly-Redefining productivity in the value chain: Improving the quality, quantity, cost, and reliability of inputs, production, and distribution in a sustainable manner. ThirdlyEnabling local cluster development: Developing a strong competitive context, including reliable local suppliers, a functioning infrastructure, access to talent, and an effective legal system.

Indian companies are beginning to experiment with creating shared value. In healthcare and sanitation, companies such as Novartis India, Vaatsalya, General Electric, and Water Health India are beginning to recognize health challenges as business opportunities. They are creating shared value by extending access to medicine to rural areas, developing innovative medical devices tailored to low-income populations, and improving sanitary conditions as well as access to clean drinking water for the underserved. In agriculture, companies such as Jain Irrigation Systems Limited, IKSL (IFFCO Kisan Sanchar Limited), eFarm, and the Gujarat Cooperative Milk Marketing Federation, Ltd. (also known as Amul) are seizing opportunities to create economic and social value by increasing agricultural productivity, creating fair and transparent markets, and collectivizing small and marginal farmers. Lastly, financial services companies such as Pay Mate, Eko India Financial Services, State Bank of India, and IFMR Rural Finance are working to bring formal services to the unbanked by providing discrete products that do not require savings accounts, by delivering basic suites of banking products and services, and even by offering financial advisory support. This research is focused on companies that take a systematic and intentional approach to creating economic and social value. In three sectors (healthcare, agriculture, and financial services) have achieved this balance and contributed to real, sustained, and inclusive growth. In each case, companies use private-sector resources to create economic value and engender sustainable social change on a large scale. The implementation of CSV principles in India is in a growing stage else the experiences of several firms, including social and small to medium enterprises, show that market-based models can have significant economic and social impact.

There are three common lessons that can help companies transition more effectively. First, a top-down approach is critical. Corporate leadership sets the tone for employees and guides decisions about allocating financial and human resources. Second, pursuing shared value is not a short-term endeavor. And third, the skills and activities required to drive CSV are often quite different from a company's traditional CSR operations. Companies should treat a shift toward CSV as they would any significant strategic effort and apply management resources and principles accordingly. To get started, focus on creating a vision and strategy to guide the way. Creating true shared value involves making use of a particular organization's skills and resources against issues that affect its operations. As firms contemplate ways to create shared value, therefore, each must determine its unique approach. In early 2011, there are 10 common building blocks. These building blocks, while each important, should not necessarily be sequentially implemented. In fact, the first several (related to vision and strategy) are often intertwined. Experience shows that one of the biggest challenges to successfully creating shared value lies in starting the process. Sometimes, a company's CEO serves as an early champion, facilitating the development of a team, a vision, and a strategy. In many cases, however, other members of the firm's leadership must make the business case internally through a focused effort that creates a strong and compelling rationale and gains the approval of senior leaders. Without commitment at the top, companies are unlikely to marshal the resources, focus, and long-term thinking required to have a meaningful effect. Thus, as a first step, proponents of creating shared value should define the stakeholders who will be most critical to championing the work. Typical candidates include the CEO, one or two influential board members, business heads, other 
executive committee members, and, in the case of family-owned businesses, key family members. Next, CSV proponents should work with the team to identify an appropriate plan for moving forward. They can begin the process by first identifying those business opportunities and constraints (for example, a lack of skilled workers) that represent strong options for the company to create large-scale, meaningful social impact by making use of its core assets and expertise. From there, the team should develop a clear strategy for creating shared value that is anchored in an explicit vision and specific social and business goals.

\section{Conclusion}

The examples of CSV can inspire companies, government, and civil society to leverage the power of business to achieve meaningful and lasting inclusive growth. Indian Corporations and Inclusive Growth creating shared value (CSV) is an approach to corporate social responsibility (CSR) that involves creating large-scale and sustainable social impact while strengthening the fundamental drivers of business competitiveness. Although greater numbers of students graduate from the nation's higher education system each year, Indian businesses struggle to hire qualified employees. Lack of quality infrastructure such as roads, railways, and urban planning raises the cost of doing business, constraining local firms and contributing to a slowdown in foreign direct investment. Corporations must play a central role. Government is often seen as the answer, but Government of India (GoI) spending alone is unlikely to be enough. Philanthropy can play only a limited role to address these problems. Despite recent increases in domestic giving, charities are generally unable to achieve sustainable scale. Although such efforts are essential, they are limited to the company's own trace and do not force large-scale social progress. Most importantly, they do not pull the core competencies to achieve an external impact.

Traditional CSR involves redistributing (or sharing) economic value, classically by giving back a small percentage of net profits and however, it focuses on creating positive social change and sustainable sources of competitive advantage. Companies who pursue CSV design products to meet customers' long-term needs, and they expand into new markets to include those who were previously excluded and such firms improve productivity while at the same time reducing their environmental In a world that still struggle with balancing economic and social growth, India has the chance to shape the path toward more conscientious value creation. Social inequity and environmental degradation are naked realities that Indians face daily however rapid economic growth, and a deep tradition of companies giving back to their nation, gives India a leg up relative to other countries that are struggling to determine the right approach. Indian corporations have an unmatched opportunity to innovate and develop business solutions that can solve social problems and ignite economic growth. So Companies must recognize social responsibility as shareholder responsibility and invest accordingly. To realize the potential of shared value, businesses must expand their mindsets beyond traditional CSR and invest in the resources (staff, funding, and research and development) necessary to craft initiatives such as those highlighted in this report. This approach is not to be taken lightly: it requires top-down commitment and real alignment with corporate strategy. Government, civil society, and the private sector all have important roles to play in India's future success. Government must create an enabling environment to incentivize corporate action. Non-governmental organizations (NGOs) exist to identify, understand, and solve social problems, and India should make use of these valuable sources of market information and knowhow. Reaching the last stop of destination is often a challenge, even for companies willing to locate staff members in rural areas. NGOs with experience working in remote locations and with difficult-to-serve consumers can significantly improve the chances of success for a company introducing new products and services. Partnerships should enable companies to focus on what they do best. Social and small to medium enterprises are discovering innovative new ways to address customer needs. All stakeholders should approach inclusive growth responsibly. Businesses, the Government of India, and civil society should work together to carefully balance economic and social benefits and to protect vulnerable populations. CSV requires a shift in your company's mindset-CSV is quite a different proposition from CSR, and companies should treat it as a long-term investment that is closely tied to business success. Such a vision often implies a significant change in mindset for employees.

\section{A. Article:-.}

\section{Bibliography}

[1]. Carroll, The Pyramind of corporate social responsibility: towards the moral management of organizational stakeholder, Business Horizons 34 (1991): 39-48.

[2]. E. Freeman, Strategic Management: A Stakeholder Approach. (Pitman Publishing) 1984

[3]. Miles, Morgan, P., Munilla, Linda, S., and Darroch, Jenny, The Role of Strategic Conversations with Stakeholders in the Formation of Corporate Social Responsibility Strategyll, Journal of Business Ethics, Vol. 69, No. 2, (2006), pp.195-205.

[4]. Tokoro. Nobuyuki, Stakeholders and Corporate Social Responsibility (CSR): A New Perspective on the Structure of Relationships, Asian Business \& Management, Vol. 6, (2007), pp. 143-162.

[5]. Porter, Michael and Kramer, Mark, How to fix Capitalism and unleash a new wave of growth, Harvard Business review, (JanuaryFebruary (2011), pp. 1-17.

[6]. Rappaport, A., Creating Shareholder Value: A Guide, (1998). 
[7]. Borgonovi, Veronica and Meier, Simon and et al), Creating Shared value in India: How Indian corporations are contributing to inclusive Growth while strengthening their competitive advantage, FSG (2011), pp. 1-55.

[8]. Porter, Michael and Kramer, Mark, How to fix Capitalism and unleash a new wave of growth, Harvard Business review (JanuaryFebruary (2011), pp. 1-17. 